\title{
Mechanism of the stimulation of insulin release in vitro by HB 699, a benzoic acid derivative similar to the non-sulphonylurea moiety of glibenclamide
}

\author{
M.-G.Garrino ${ }^{1}$, W.Schmeer ${ }^{2}$, M. Nenquin ${ }^{1}$, H.P. Meissner ${ }^{2}$ and J.C. Henquin ${ }^{1,2}$ \\ ${ }^{1}$ Unité de Diabétologie et Nutrition, University of Louvain, Faculty of Medicine, Brussels, Belgium, and \\ ${ }^{2}$ I Physiologisches Institut and Medizinische Klinik, University of Saarland, Homburg/Saar, Germany
}

\begin{abstract}
Summary. HB 699 is a benzoic acid derivative similar to the non-sulphonylurea moiety of glibenclamide. The mechanisms whereby it affects B-cell function have been studied in vitro with mouse islets. In the presence of $3 \mathrm{mmol} / 1$ glucose, HB 699 decreased ${ }^{86} \mathrm{Rb}^{+}$efflux and accelerated ${ }^{45} \mathrm{Ca}^{2+}$ efflux from islet cells, depolarized the B-cell membrane and induced an electrical activity similar to that triggered by stimulatory concentrations of glucose, and increased insulin release. The changes in ${ }^{45} \mathrm{Ca}^{2+}$ efflux and insulin release, but not the inhibition of ${ }^{86} \mathrm{Rb}^{+}$efflux, were abolished in the absence of $\mathrm{Ca}^{2+}$. In the presence of $10 \mathrm{mmol} / 1$ glucose, HB 699 increased ${ }^{86} \mathrm{Rb}^{+}$and ${ }^{45} \mathrm{Ca}^{2+}$ efflux from the islets, caused a persistent depolarization of the B-cell membrane with continuous electrical activity, and markedly potentiated insulin release. All these changes were suppressed by omission of extracellular
\end{abstract}

$\mathrm{Ca}^{2+}$. In the presence of $15 \mathrm{mmol} / 1$ glucose, diazoxide increased ${ }^{86} \mathrm{Rb}^{+}$efflux, hyperpolarized the B-cell membrane, suppressed electrical activity and inhibited insulin release. HB 699 reversed these effects of diazoxide. It is suggested that HB 699 decreases $\mathrm{K}^{+}$permeability of the B-cell membrane, thereby causing a depolarization which leads to activation of voltage-dependent $\mathrm{Ca}$ channnels and $\mathrm{Ca}^{2+}$ influx, and eventually increases insulin release. A sulphonylurea group is thus not a prerequisite to trigger the sequence of events that is also thought to underlie the releasing effects of tolbutamide and glibenclamide.

Key words: Insulin release, ionic fluxes, membrane potential, isolated islets, B-cells, sulphonylureas, benzoic acid derivative.
It has been known for 25 years that hypoglycaemic sulphonamides stimulate insulin release, but the mechanisms by which they affect B-cell function are only partially elucidated [1]. The most effective compounds contain a sulphonylurea group, that was long regarded as an essential structural requirement for the insulin-releasing action. However, it has been reported a few years ago [2] that compound HB 699 or (4-[2-(5-chloro-2 methoxybenzamide)-ethyl]-benzoic acid), which is similar to the non-sulphonylurea moiety of glibenclamide (Fig. 1), also possesses hypoglycaemic properties. This hypoglycaemic action is due to a stimulation of insulin release, that was demonstrated in vivo $[2,3]$, and in vitro $[2,4-6]$. The cellular mechanisms of this stimulation are not known and may conceivably be quite different from those of the parent molecule glibenclamide. In vivo studies of various hypoglycaemic compounds have indeed led to the speculation that HB 699 and sulphonylureas interact with the same site [7] or with two different sites [8] on B cells. Recent in vitro experiments were also suggestive of different modes of action [9].

In this study we have thus measured the effects of HB 699 on ${ }^{86} \mathrm{Rb}^{+}$or ${ }^{45} \mathrm{Ca}^{2+}$ efflux, and on insulin re- lease from mouse islets, as well as on the membrane potential of mouse B cells. These effects have also been compared to those of glibenclamide.

\section{Materials and methods}

All experiments were performed with islets of fed female NMRI mice $(25-30 \mathrm{~g})$, killed by decapitation. For electrophysiological experiments, a piece of pancreas was fixed in a small perifusion chamber, and the membrane potential of single $B$ cells was continuously re-

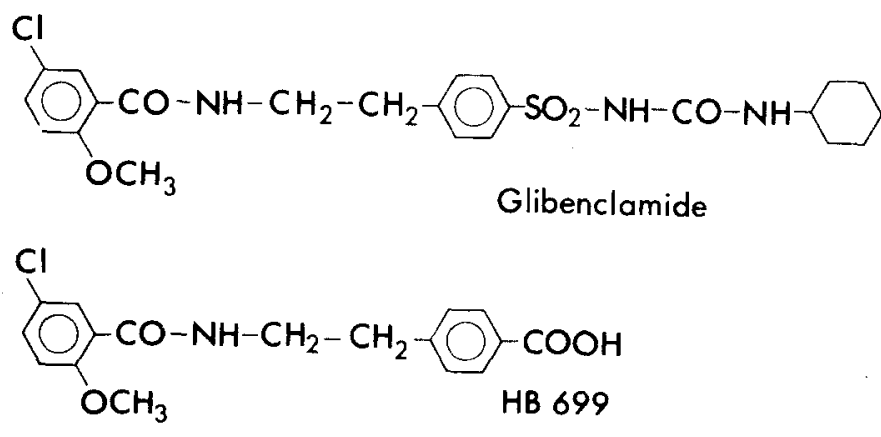

Fig. 1. Structural formulae of glibenclamide and compound HB 699 

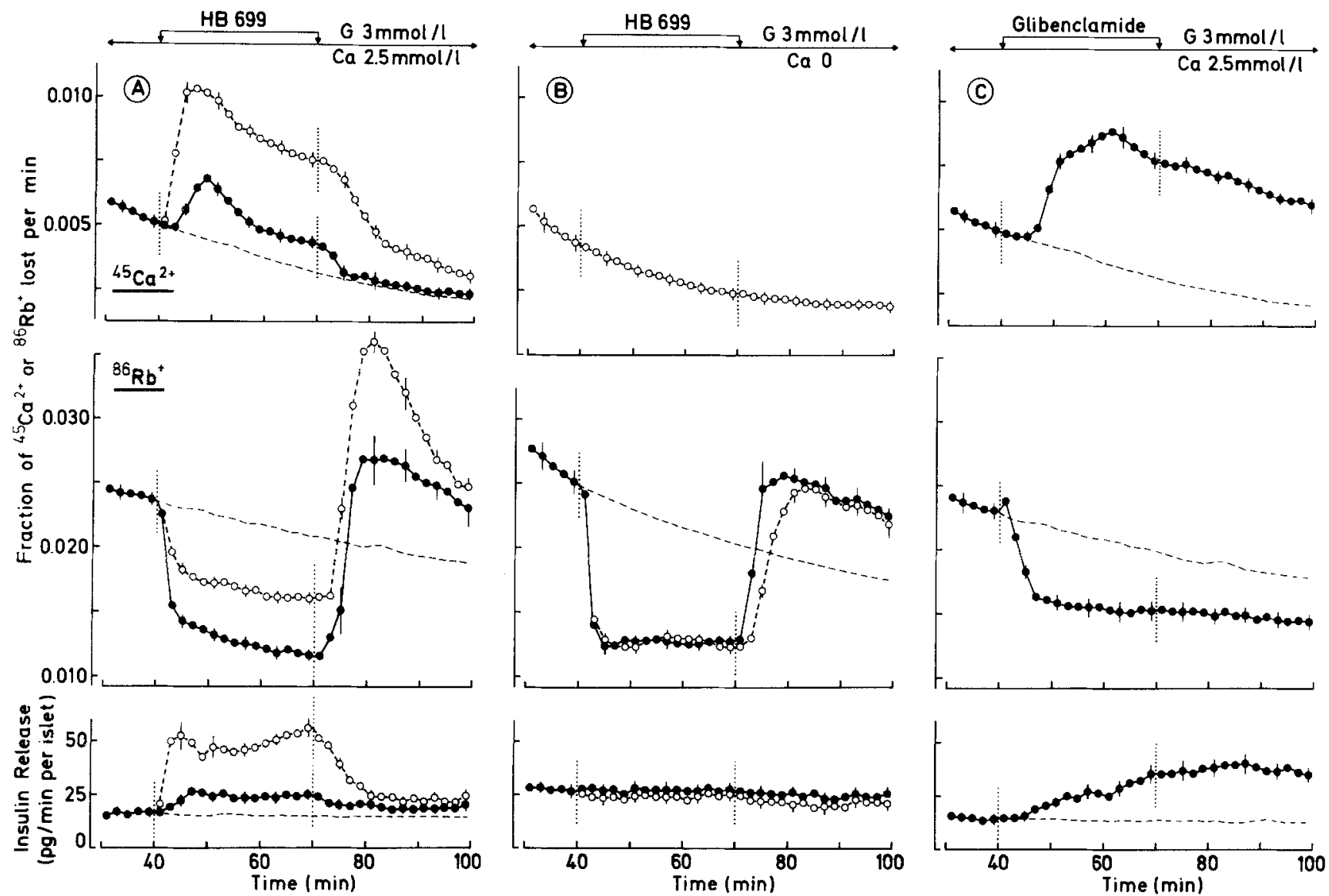

Fig. 2A-C. Effects of HB 699 and glibenclamide on ${ }^{45} \mathrm{Ca}^{2+}$ or ${ }^{86} \mathrm{Rb}^{+}$efflux, and on insulin release from mouse islets perifused with a medium containing a non-stimulatory concentration of glucose $(\mathrm{G} 3 \mathrm{mmol} / \mathrm{l})$. The medium contained $2.5 \mathrm{mmol} / 1 \mathrm{Ca}^{2+}$ in $\mathrm{A}$ and $\mathrm{C}$, and no $\mathrm{Ca}^{2+}$ in $\mathrm{B}$.

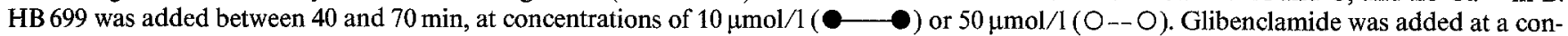
centration of $0.1 \mu \mathrm{mol} / 1$. Controls without addition of test substance are shown by the broken lines. Values are means \pm SEM for $4-5$ experiments
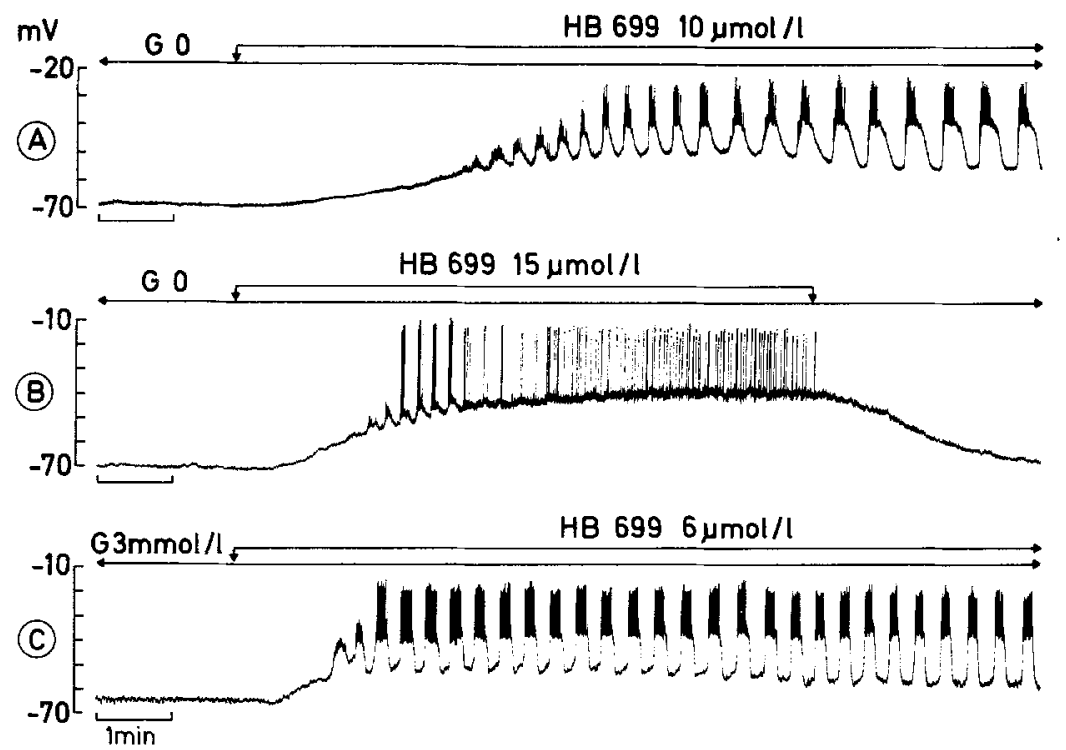

Fig. 3A-C. Effects of HB 699 on the membrane potential of single mouse B-cells perifused with a medium containing no glucose (GO) (A and $\mathrm{B}$ ) or $3 \mathrm{mmol} / \mathrm{l}$ glucose $(C)$. HB 699 was added at the indicated concentrations and for the periods shown by the arrows. The three records were obtained in different cells and are representative of 6 experiments

corded with microelectrodes [10]. B cells were identified by the typical electrical activity that they display in the presence of $10-15 \mathrm{mmol} / 1$ glucose [11]. For all other experiments, islets were isolated after collagenase digestion of the pancreas. Details of the method used to monitor the efflux of ${ }^{86} \mathrm{Rb}^{+}$(used as tracer for $\mathrm{K}^{+}$) or ${ }^{45} \mathrm{Ca}^{2+}$ from preloaded islets have been reported elsewhere [12]. During the experiments of ${ }^{86} \mathrm{Rb}^{+}$efflux, a portion of each effluent fraction was drawn for measurement of immunoreactive insulin, with rat insulin as standard [13].

The perifusion medium used was a bicarbonate-buffered solution, pH 7.4 [14], that was supplemented with bovine serum albumin (1 mg/ $\mathrm{mI}$ ), except for electrophysiological recordings. In certain experiments, $\mathrm{CaCl}_{2}$ was omitted and replaced by $\mathrm{MgCl}_{2}$; its total concentration was less than $20 \mu \mathrm{mol} / \mathrm{l}$. 

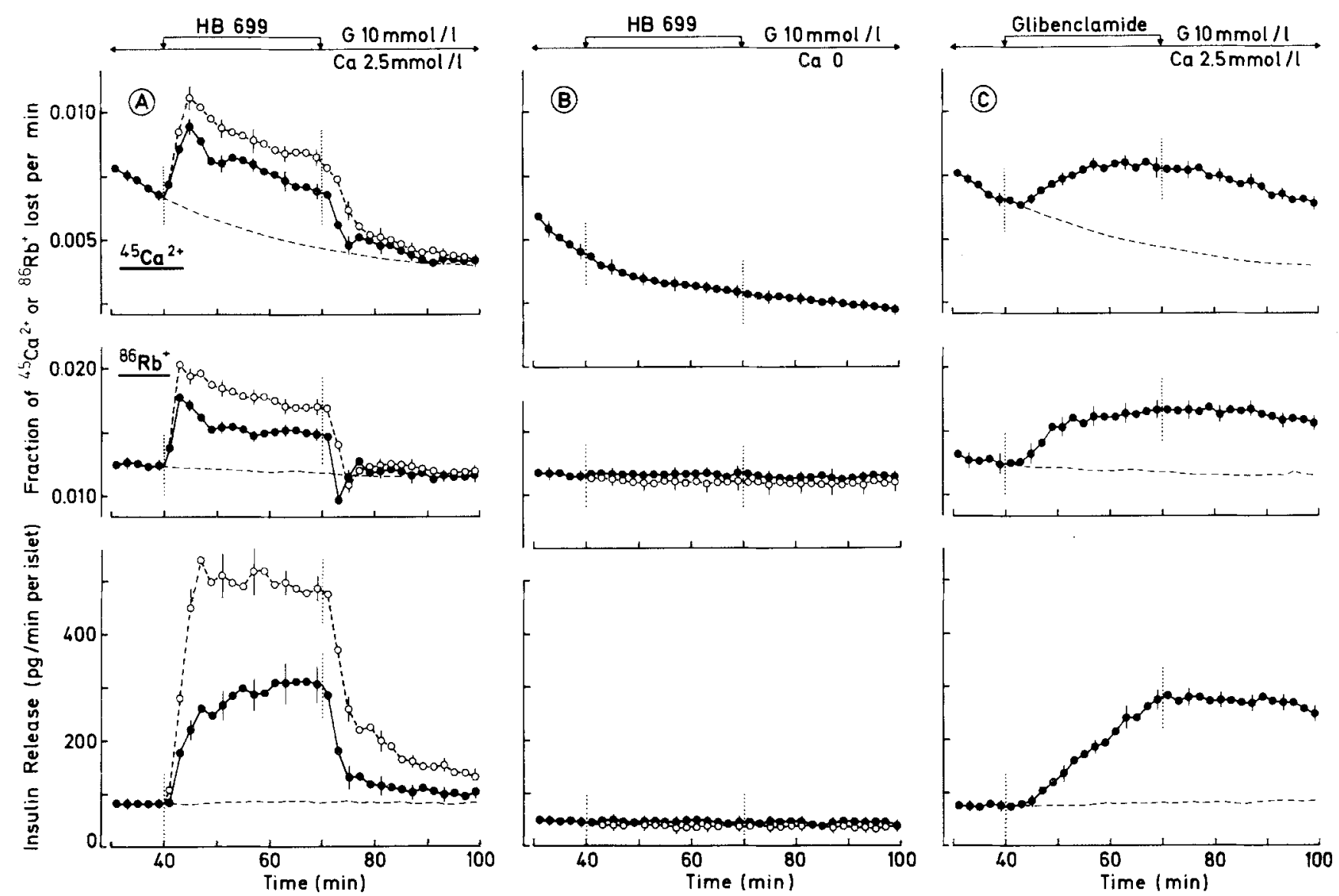

Fig.4A-C. Effects of HB 699 and glibenclamide on ${ }^{45} \mathrm{Ca}^{2+}$ or ${ }^{86} \mathrm{Rb}^{+}$efflux, and on insulin release from mouse islets perifused with a medium containing a stimulatory concentration of glucose $(\mathrm{G} 10 \mathrm{mmol} / 1)$. The medium contained $2.5 \mathrm{mmol} / 1 \mathrm{Ca}^{2+}$ in $\mathrm{A}$ and $\mathrm{C}$, and no Ca ${ }^{2+}$ in $\mathrm{B}$. $\mathrm{HB} 699$ was added between 40 and $70 \mathrm{~min}$, at concentrations of $2 \mu \mathrm{mol} / 1(-\longrightarrow)$ or $10 \mu \mathrm{mol} / 1\left(\mathrm{O}_{--} \mathrm{O}\right)$. Glibenclamide was added at a concentration of $0.02 \mu \mathrm{mol} / \mathrm{l}$. Controls without addition of test substance are shown by the broken lines. Values are means \pm SEM for 4 experiments

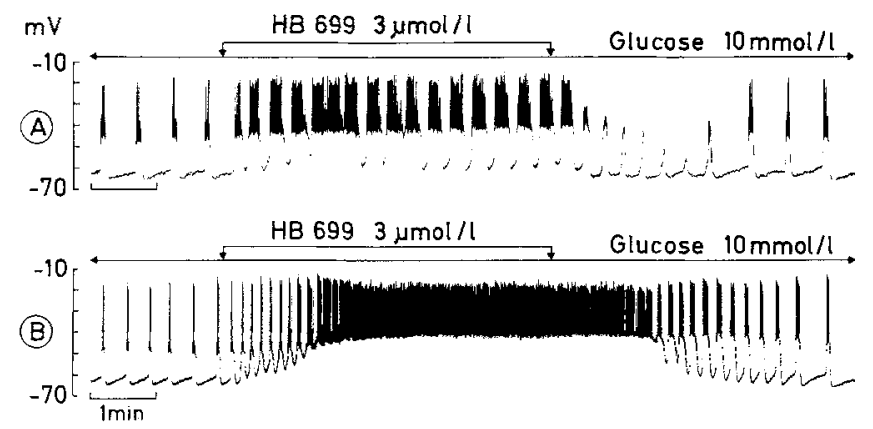

Fig.5A and B. Effects of HB 699 on the membrane potential of single mouse B-cells perifused with a medium containing $10 \mathrm{mmol} / 1$ glucose. HB $699(3 \mu \mathrm{mol} / \mathrm{l})$ was added as indicated by the arrows. The two records were obtained in different cells and are representative of 4 experiments

HB 699 and glibenclamide were provided by Hoechst A.G. (Frankfurt, FRG) and diazoxide by Schering Corp. (Bloomfield, NJ, USA). Stock solutions were freshly prepared each day (in $0.1 \mathrm{~mol} / 1$ $\mathrm{NaOH}$ ) and aliquots were added to the appropriate media just before use. ${ }^{86} \mathrm{RbCl}$ and ${ }^{45} \mathrm{CaCl}_{2}$ were purchased from the Radiochemical Center (Amersham, Bucks, UK). All other reagents were from Merck AG (Darmstadt, FRG).

Electrophysiological experiments are illustrated by recordings, which are representative of the indicated number of experiments, per- formed with different mice. Other results are presented as means \pm SEM for the indicated number of experiments, performed with different islet preparations.

\section{Results}

\section{Effects of HB 699 in the presence of a non-stimulatory concentration of glucose}

Addition of 10 or $50 \mu \mathrm{mol} / 1 \mathrm{HB} 699$ to a medium containing $3 \mathrm{mmol} / 1$ glucose and $2.5 \mathrm{mmol} / 1 \mathrm{Ca}^{2+}$ caused an acceleration of ${ }^{45} \mathrm{Ca}^{2+}$ efflux, an inhibition of ${ }^{86} \mathrm{Rb}^{+}$ efflux and a stimulation of insulin release from perifused islets (Fig. 2A). The changes in ${ }^{45} \mathrm{Ca}^{2+}$ efflux and insulin release were dose-dependent, whereas the decrease in ${ }^{86} \mathrm{Rb}^{+}$efflux was more marked with 10 than with $50 \mu \mathrm{mol} / 1 \mathrm{HB} 699$. If the medium did not contain $\mathrm{Ca}^{2+}$, HB 699 did not affect ${ }^{45} \mathrm{Ca}^{2+}$ efflux or insulin release, but still decreased ${ }^{86} \mathrm{Rb}^{+}$efflux (Fig. 2 B). This inhibitory effect reached a steady value sooner than in the presence of $\mathrm{Ca}^{2+}$ and was similar with both concentrations of the drug. All effects of HB 699 were reversible upon removal of the drug. In the absence of glucose, $50 \mu \mathrm{mol} / 1 \mathrm{HB} 699$ rapidly decreased ${ }^{86} \mathrm{Rb}^{+}$efflux and 

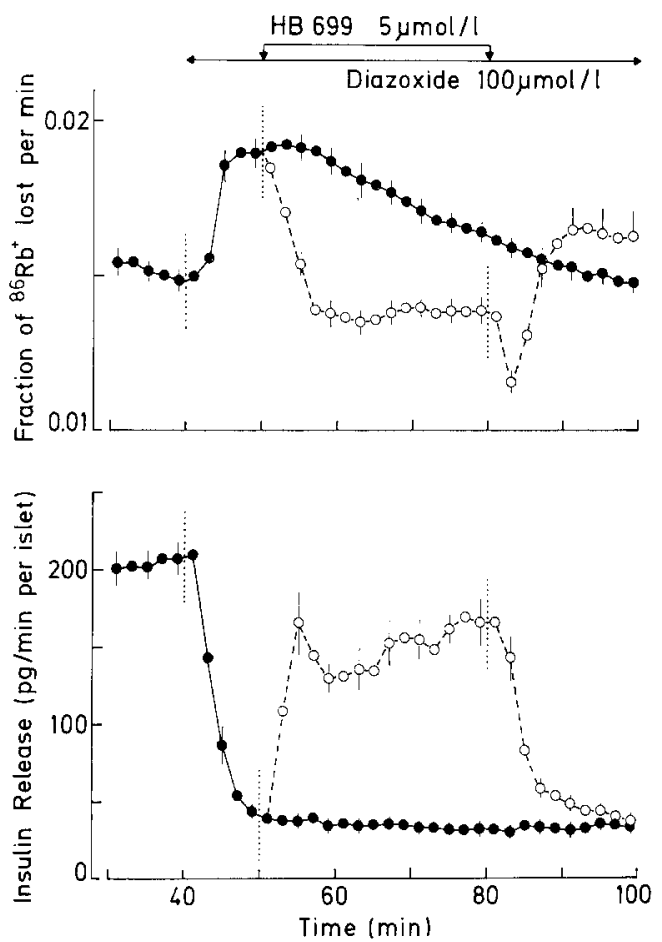

Fig. 6. Reversal by HB 699 of the effects of diazoxide on ${ }^{86} \mathrm{Rb}^{+}$efflux and on insulin release from mouse islets perifused with a medium containing $15 \mathrm{mmol} / \mathrm{l}$ glucose. Diazoxide $(100 \mathrm{umol} / \mathrm{l})$ was added between 40 and $100 \mathrm{~min}$. HB $699(5 \mu \mathrm{mol} / \mathrm{l})$ was added in one series $(\mathrm{O}-\mathrm{O})$, between 50 and $80 \mathrm{~min}$. Values are means $\pm \mathrm{SEM}$ for 6 experiments
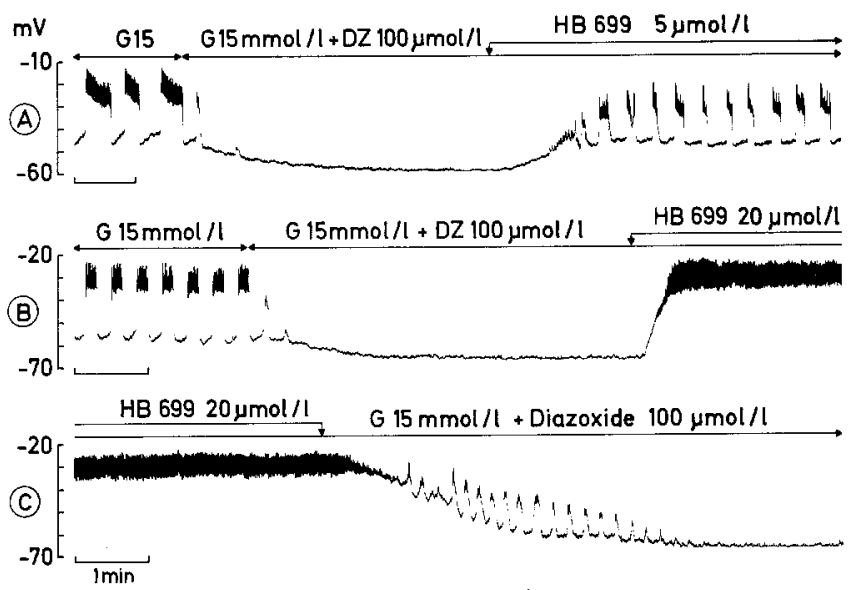

Fig. 7A-C. Reversal by HB 699 of the effects of diazoxide on the membrane potential of single mouse B-cells perifused with a medium containing $15 \mathrm{mmol} / \mathrm{l}$ glucose (G). Diazoxide (DZ) and HB 699 were added at the indicated concentrations and for the periods shown by the arrows. RecordC is the direct continuation of record B. Record A was obtained in another cell. These records are representative of 5 experiments

increased ${ }^{45} \mathrm{Ca}^{2+}$ efflux and insulin release with a slight delay. At the concentration of $10 \mu \mathrm{mol} / \mathrm{l}, \mathrm{HB} 699$ also decreased ${ }^{86} \mathrm{Rb}^{+}$efflux, but did not consistently affect ${ }^{45} \mathrm{Ca}^{2+}$ efflux and insulin release (not shown).

When the islets were perifused with a glucose-free medium containing $2.5 \mathrm{mmol} / 1 \mathrm{Ca}^{2+}, 10 \mu \mathrm{mol} / 1$
HB 699 slowly depolarized the B-cell membrane and induced electrical activity (Fig. $3 \mathrm{~A}$ ). This activity consisted of slow waves of the membrane potential with spikes superimposed on the plateau. A lower concentration of HB $699(3 \mu \mathrm{mol} / 1)$ consistently depolarized the B-cell membrane, but induced electrical activity only transiently in 2 cells out of 4 (not shown). A higher concentration of HB $699(15 \mu \mathrm{mol} / 1)$ caused a more rapid and persistent depolarization of the B-cell membrane, with a continuous spike activity (Fig. 3 B). Removal of HB 699 was followed by disappearance of the electrical activity and repolarization of the membrane. At a concentration of $3 \mathrm{mmol} / \mathrm{l}$, glucose alone did not affect the membrane potential of B-cells, but amplified the effects of HB 699 (Fig. 3C).

Glibenclamide $(0.1 \mu \mathrm{mol} / \mathrm{l})$ accelerated ${ }^{45} \mathrm{Ca}^{2+}$ efflux, inhibited ${ }^{86} \mathrm{Rb}^{+}$efflux and increased insulin release from islets perifused with a medium containing $3 \mathrm{mmol} / 1$ glucose (Fig. 2C). These effects of glibenclamide were slower than those of HB 699 and were not readily reversible by removal of the drug. Under these conditions, glibenclamide slowly depolarized the B-cell membrane and induced a continuous spike activity (not shown). Omission of $\mathrm{Ca}^{2+}$ abolished the changes in ${ }^{45} \mathrm{Ca}^{2+}$ efflux and insulin release otherwise brought about by glibenclamide, but amplified its inhibitory effect on ${ }^{86} \mathrm{Rb}^{+}$efflux (not shown).

\section{Effects of HB 699 in the presence of a stimulatory concentration of glucose}

When the perifusion medium contained $10 \mathrm{mmol} / 1 \mathrm{glu}-$ cose and $2.5 \mathrm{mmol} / 1 \mathrm{Ca}^{2+}$, the rates of ${ }^{45} \mathrm{Ca}^{2+}$ efflux and of insulin release were higher, whereas the rate of ${ }^{86} \mathrm{Rb}^{+}$efflux was lower than in the presence of $3 \mathrm{mmol} / 1$ glucose. Addition of 2 or $10 \mu \mathrm{mol} / 1 \mathrm{HB} 699$ caused a dose-dependent, reversible increase in ${ }^{45} \mathrm{Ca}^{2+}$ efflux, ${ }^{86} \mathrm{Rb}^{+}$efflux and insulin release from the islets (Fig. 4A). All these changes were abolished in the absence of $\mathrm{Ca}^{2+}$ (Fig. $4 \mathrm{~B}$ ).

The electrical activity induced by $10 \mathrm{mmol} / 1$ glucose in B-cells was rapidly, markedly and reversibly modified by $3 \mu \mathrm{mol} / 1 \mathrm{HB} 699$. In certain cells, the drug increased the duration of the slow waves with spike activity, and decreased both the duration and the amplitude of the polarized intervals (Fig.5A). In other cells, HB 699 persistently depolarized the membrane to the plateau level and induced a continuous spike activity (Fig. 5 B).

Glibenclamide $(0.02 \mu \mathrm{mol} / 1)$ accelerated ${ }^{45} \mathrm{Ca}^{2+}$ and ${ }^{86} \mathrm{Rb}^{+}$efflux, and increased insulin release from islets perifused with a medium containing $10 \mathrm{mmol} / 1 \mathrm{glu}$ cose (Fig. 4C). These effects of glibenclamide were slower than those of HB 699 and were not reversible upon removal of the drug. Under similar conditions, glibenclamide persistently depolarized the B-cell membrane to the plateau level and induced a continuous spike activity (not shown). In the absence of extracellu- 
lar $\mathrm{Ca}^{2+}$, the changes in ionic fluxes and insulin release otherwise brought about by glibenclamide were abolished (not shown).

\section{Antagonistic effects of $\mathrm{HB} 699$ and diazoxide}

In islets perifused with a medium containing $15 \mathrm{mmol} / \mathrm{l}$ glucose, $100 \mu \mathrm{mol} / 1$ diazoxide caused a simultaneous increase in ${ }^{86} \mathrm{Rb}^{+}$efflux and inhibition of insulin release. Addition of $5 \mu \mathrm{mol} / 1 \mathrm{HB} 699$ to the medium containing diazoxide reversed these changes in a reversible manner (Fig. 6).

Glucose-induced electrical activity rapidly stopped upon addition of diazoxide, and the B-cell membrane markedly hyperpolarized (Fig. 7). Subsequent introduction of HB 699 reversed these effects in a dose-dependent manner. The restoration of the electrical activity was only partial with $5 \mu \mathrm{mol} / 1 \mathrm{HB} 699$. On the other hand $20 \mu \mathrm{mol} / 1 \mathrm{HB} 699$ depolarized the B-cell membrane to the plateau level and induced continuous spike activity, despite the presence of diazoxide. Withdrawal of HB 699 was followed by repolarization of the B-cell membrane (Fig. $7 \mathrm{C}$ ).

\section{Discussion}

This study shows that the stimulation of insulin release by HB 699, a benzoic acid derivative corresponding to the non-sulphonylurea moiety of glibenclamide, is accompanied by changes in ${ }^{45} \mathrm{Ca}^{2+}$ efflux, ${ }^{86} \mathrm{Rb}^{+}$efflux and B-cell membrane potential qualitatively similar to those induced by tolbutamide [15-18] or by glibenclamide itself. A precise estimation of their relative potencies was not the purpose of the study. However, comparison of the present data with published [15-20] and unpublished results (J.C.H. and H.P.M.) shows that, on all parameters measured here, HB 699 is slightly more potent $(2-5 \mathrm{X})$ than tolbutamide, but much less potent $(100-200 \mathrm{X})$ than glibenclamide. Also by the rapidity of onset and reversibility of its effects HB 699 resembles tolbutamide more than glibenclamide, all effects of which are slower and not readily reversible upon washing [21-23]. Finally, it should be pointed out that the concentration of free HB 699 is likely to be higher in electrophysiological experiments which are carried out in the absence of albumin than in other experiments. Comparison of the effects of a given concentration of the drug on membrane potential and on other aspects of the B-cell function should thus be made with this reservation in mind. In particular, this may explain why, in the absence of glucose, $10 \mu \mathrm{mol} / 1 \mathrm{HB} 699$ depolarized the B-cell membrane (and decreased ${ }^{86} \mathrm{Rb}^{+}$ efflux), but failed to stimulate ${ }^{45} \mathrm{Ca}^{2+}$ efflux and insulin release.

There is now general agreement that an increase of $\mathrm{Ca}^{2+}$ influx in B cells is an essential step in the stimulation of insulin release by sulphonylureas. This con- sensus is based on measurements of both ${ }^{45} \mathrm{Ca}^{2+}$ fluxes in islet cells $[15,17,24-26]$ and membrane potential in $\mathrm{B}$ cells $[16,18,19,22,27]$. The possible role of $\mathrm{Ca}^{2+}$ in the B-cell response to HB 699 has been addressed in three studies, but the results are conflicting. From measurements of ${ }^{45} \mathrm{Ca}^{2+}$ uptake by $o b / o b$ mouse islets, it was concluded that the effects of $\mathrm{HB} 699$ on the $\mathrm{Ca}^{2+}$ permeability of the B-cell membrane are not the same as those of glibenclamide or tolbutamide [28]. It was proposed that a mobilization of cellular $\mathrm{Ca}^{2+}$ contributes to the releasing action of HB 699. Such a view is compatible with the report that omission of extracellular $\mathrm{Ca}^{2+}$ inhibited HB 699-induced insulin release only partially in incubated rat islets [6]. On the other hand, the stimulation of release and the increase in ${ }^{45} \mathrm{Ca}^{2+}$ content of rat islets brought about by a very high concentration of HB $699(1.2 \mathrm{mmol} / \mathrm{l})$ were found to be inhibited by verapamil, a blocker of voltage-dependent Ca-channels [29].

In the present study, the stimulatory effect of HB 699 (and of glibenclamide) on insulin release and ${ }^{45} \mathrm{Ca}^{2+}$ efflux displayed similar time-course and dosedependency. Both changes were abolished by omission of extracellular $\mathrm{Ca}^{2+}$. Analogous observations have been made with tolbutamide [17] and gliclazide [26], and interpreted as evidence for a stimulation of $\mathrm{Ca}^{2+}$ influx (with secondary displacement of radioactive cellular ${ }^{45} \mathrm{Ca}^{2+}$ ), without any substantial direct effect of the drugs on intracellular $\mathrm{Ca}^{2+}$ stores. The appearance or the increase of an electrical activity underlain by $\mathrm{Ca}^{2+}$ inward currents [30] also fully supports the contention that HB 699 increases insulin release by stimulating $\mathrm{Ca}^{2+}$ influx in B cells.

The membrane potential of non-stimulated $B$ cells is mainly determined by the high relative $\mathrm{K}^{+}$permeability of the plasma membrane [31]. Qualitative changes of this latter can be established by measuring ${ }^{86} \mathrm{Rb}^{+}$efflux from islet cells in parallel with the membrane potential [30]. The observations that HB 699 simultaneously decreased ${ }^{86} \mathrm{Rb}^{+}$efflux and depolarized the B-cell membrane strongly suggest that the drug decreases $\mathrm{K}^{+}$permeability of the B-cell membrane and that this decrease is the cause of the depolarization. A similar mechanism is believed to cause the depolarization produced by tolbutamide or glibenclamide $[15,16,18,19,32]$.

Unlike the changes in ${ }^{45} \mathrm{Ca}^{2+}$ efflux or insulin release, the changes in ${ }^{86} \mathrm{Rb}^{+}$efflux induced by HB 699 were not always dose-dependent. In a medium containing $3 \mathrm{mmol} / 1$ glucose, the inhibition of efflux was more marked with 10 than with $50 \mu \mathrm{mol} / 1 \mathrm{HB} 699$, whereas the rebound following removal of the drug was more concentration-dependent. Moreover, this peculiarity, which also characterizes the effect of tolbutamide $[18$, 32], was only observed in the presence of $\mathrm{Ca}^{2+}$. It can be ascribed to the activation of $\mathrm{K}$ channels by the greater influx of $\mathrm{Ca}^{2+}$ [12] and more sustained depolarization of the B-cell membrane in the presence of the highest concentrations of HB 699 or tolbutamide. 
It is currently admitted that the repolarization phase of the slow waves of membrane potential induced by glucose in B cells is, at least partially, due to an increase in $\mathrm{K}^{+}$permeability [30]. The lengthening of these slow waves and the decrease in duration and amplitude of the polarized intervals in certain cells, as well as the sustained depolarization at the plateau level in other cells, suggest that HB 699 also reduces $\mathrm{K}^{+}$permeability of the B-cell membrane in the presence of a stimulatory concentration of glucose. Such a conclusion may seem in contradiction with the acceleration of ${ }^{86} \mathrm{Rb}^{+}$efflux produced by the drug under these conditions. However, similar changes occur upon addition of tolbutamide [15, $18,33]$ or leucine $[34,35]$ to a medium containing a stimulatory concentration of glucose, although the genuine effect of these substances is to decrease the $\mathrm{K}^{+}$ permeability of the B-cell membrane. This paradoxical increase in ${ }^{86} \mathrm{Rb}^{+}$efflux, which did not occur in the absence of $\mathrm{Ca}^{2+}$ and which was paralleled by the stimulation of ${ }^{45} \mathrm{Ca}^{2+}$ efflux by HB 699, can be explained by the activation of $\mathrm{K}$-channels by the incoming $\mathrm{Ca}^{2+}[12]$, and by the more sustained depolarization of the membrane.

We have previously demonstrated that the inhibition of insulin release by diazoxide is due to the ability of this sulphonamide to hyperpolarize the B-cell membrane by increasing its permeability to $\mathrm{K}^{+}[18]$. The present study confirms this mechanism of action and further shows that HB 699 is able to reverse the effects of diazoxide on ${ }^{86} \mathrm{Rb}^{+}$efflux, B-cell membrane potential and insulin release. This property, shared with tolbutamide, tetraethylammonium, quinine and sparteine $[18,36]$ lends further support to the proposal that HB 699 affects B-cell function by decreasing the $\mathrm{K}^{+}$ permeability of the plasma membrane.

In conclusion, the following sequence of events, can be proposed for the stimulation of insulin release by HB 699. The drug decreases $\mathrm{K}^{+}$permeability of the Bcell membrane and, thereby, causes depolarization. This activates voltage-dependent $\mathrm{Ca}$-channels and permits $\mathrm{Ca}^{2+}$ influx. The same sequence has been proposed to explain the releasing action of tolbutamide and glibenclamide $[15,16,18,19,32]$. This underlines the crucial importance of K-channels of B cells as targets for pharmacological insulinotropic agents, and demonstrates that a sulphonylurea group is not a prerequisite for the interaction with these channels. Further studies will help to elucidate the molecular requirements for such interaction and, hopefully, open new perspectives for designing insulinotropic drugs.

Acknowledgements. This work was supported by grant 3.4552.81 from the Fonds de la Recherche Scientifique Médicale, Brussels, and by the Deutsche Forschungsgemeinschaft, Sonderforschungsbereich 38, Bonn-Bad Godesberg. J.C.H. is "Chercheur Qualifie" of the Fonds National de la Recherche Scientifique, Brussels. The technical assistance of F. Mathot and the editorial help of M. Dechamps are gratefully acknowledged.

\section{References}

1. Gylfe E, Hellman B, Sehlin J, Täljedal I-B (1984) Interaction of sulfonylurea with the pancreatic B-cell. Experientia 40: 1126-1134

2. Geisen K, Hübner M, Hitzel V, Hrstka VE, Pfaff W, Bosies E, Regitz G, Kühnle HF, Schmidt FH, Weyer R (1978) Acylaminoalkylsubstituierte Benzoe- und Phenylalkansäuren mit blutglukosesenkender Wirkung. Arzneimittelforsch 28: 1081-1083

3. Ribes G, Trimble ER, Blayac JP, Wollheim CB, Puech R, Loubatières-Mariani MM (1981) Effect of a new hypoglycaemic agent (HB 699) on the in vivo secretion of pancreatic hormones in the dog. Diabetologia 20: 501-505

4. Blayac JP, Loubatières-Mariani MM, Ribes G (1979) Effets in vitro d'un dérivé acyl-amino-alkyl de l'acide benzoïque: le HB 699 , sur la sécrétion d'insuline et de glucagon. J Pharmacol (Paris) 10: 229-238

5. Efendic S, Enzmann F, Gutniak M, Nylen A, Zoltobrocki M (1981) Insulin, glucagon and somatostatin in the perfused rat pancreas and the effects of HB 699 (4-(2-(5 chloro-2 methoxy-benzamido)-ethyl)-benzoic acid). Acta Endocrinol 98:573-579

6. Glatt M, Schatz H (1981) The influence of an acyl-amino-alcylbenzoic acid (HB 699) on biosynthesis and secretion of insulin in isolated rat islets of Langerhans. Diabete Metab 7: 105-108

7. Brown GR, Foubister AJ (1984) Receptor binding sites of hypoglycemic sulfonylureas and related [(Acylamino)alkyl] benzoic acids. J Med Chem 27: 79-81

8. Rufer C, Losert W (1979) Blood glucose lowering sulfonamides with asymmetric carbon atoms. Related $\mathrm{N}$-substituted carbamoylbenzoic acids. J Med Chem 22: 750-752

9. Norlund L, Sehlin J (1984) The acyl-amino-alkyl benzoic acid residue and the sulfonylurea containing residue of glibenclamide affect different aspects of $\beta$-cell function. Acta Physiol Scand 120: 283-286

10. Meissner HP, Schmelz H (1974) Membrane potential of beta-cells in pancreatic islets. Pflügers Arch 351: 195-206

11. Meissner HP (1976) Electrical characteristics of the beta-cells in pancreatic islets. J Physiol (Paris) 72: 757-767

12. Henquin JC (1979) Opposite effects of intracellular $\mathrm{Ca}^{2+}$ and glucose on $\mathrm{K}^{+}$permeability of pancreatic islet cells. Nature 280 : 66-68

13. Henquin JC, Lambert AE (1975) Cobalt inhibition of insulin secretion and calcium uptake by isolated rat islets. Am J Physiol 228: $1669-1677$

14. Henquin JC, Meissner HP (1983) Dibutyryl cyclic AMP triggers $\mathrm{Ca}^{2+}$ influx and $\mathrm{Ca}^{2+}$-dependent electrical activity in pancreatic B-cells. Biochem Biophys Res Commun 112: 614-620

15. Henquin JC (1980) Tolbutamide stimulation and inhibition of insulin release: studies of the underlying ionic mechanisms in isolated rat islets. Diabetologia 18: 151-160

16. Meissner HP, Preissler M, Henquin JC (1980) Possible ionic mechanisms of the electrical activity induced by glucose and tolbutamide in pancreatic B-cells. In: Waldhäusl WK (ed) Diabetes 1979. Excerpta Medica, Amsterdam, ICS 500, pp 166-171

17. Hellman B (1981) Tolbutamide stimulation of ${ }^{45} \mathrm{Ca}$ fluxes in microdissected pancreatic islets rich in $\beta$-cells. Mol Pharmacol 20: $83-88$

18. Henquin JC, Meissner HP (1982) Opposite effects of tolbutamide and diazoxide on ${ }^{86} \mathrm{Rb}^{+}$fluxes and membrane potential in pancreatic B-cells. Biochem Pharmacol 31: 1407-1415

19. Ferrer R, Atwater I, Omer EM, Gonçalves AA, Croghan PC, Rojas E (1984) Electrophysiological evidence for the inhibition of potassium permeability in pancreatic B cells by glibenclamide. Quart J Exp Physiol 69: 831-839

20. Pace CS (1984) Influence of a tumor-promoting phorbol ester on the electrical response of B-cells to glucose and glyburide. Mol Pharmacol 26: 267-271

21. Loubatières A, Mariani MM, Ribes $G$, de Malbose $H$, Chapal $J$ (1969) Etude expérimentale d'un nouveau sulfamide hypoglycémiant particulièrement actif, le HB 419 ou glibenclamide. Diabetologia $5: 1-10$ 
22. Meissner HP, Atwater I (1976) The kinetics of electrical activity of beta-cells in response to a square wave stimulation with glucose or glibenclamide. Horm Metab Res 8: 11-16

23. Hellman B, Sehlin J, Täljedal I-B (1984) Glibenclamide is exceptional among hypoglycaemic sulphonylureas in accumulating progressively in $\beta$-cell-rich pancreatic islets. Acta Endocrinol 105: $385-390$

24. Malaisse WJ, Mahy M, Brisson GR, Malaisse-Lagae F (1972) The stimulus-secretion coupling of glucose-induced insulin release. VIII Combined effects of glucose and sulfonylureas. Eur J Clin Invest 2: $85-90$

25. Hellman B, Lenzen S, Sehlin J, Täljedal I-B (1977) Effect of various modifiers of insulin release on the lanthanum-nondisplaceable ${ }^{45} \mathrm{Ca}^{2+}$ uptake by isolated pancreatic islets. Diabetologia 13: 49-53

26. Lebrun P, Malaisse WJ, Herchuelz A (1982) Modalities of gliclazide-induced $\mathrm{Ca}^{2+}$ influx into the pancreatic B-cell. Diabetes 31: $1010-1015$

27. Matthews EK, Dean PM, Sakamoto Y (1973) Biophysical effects of sulphonylureas on islet cells. In: Okita GT and Acheson GM (eds) Pharmacology and the future of man. Karger, Basel, pp 221-229

28. Norlund L, Sehlin J (1984) Different effects of glibenclamide and the structural analogue HB 699 on the ${ }^{45} \mathrm{Ca}^{2+}$ uptake by $o b / o b$ mouse islets. Acta Physiol Scand 122: 187-190

29. Puech R, Manteghetti M, Ribes G, Wollheim CB, LoubatièresMariani MM (1985) Enhancement of insulin release and islet cell calcium content by an acyl-amino-alcyl benzoic acid derivative, HB 699. Horm Metab Res 17:1-4

30. Henquin JC, Meissner HP (1984) Significance of ionic fluxes and changes in membrane potential for stimulus-secretion coupling in pancreatic B-cells. Experientia 40: 1043-1052
31. Meissner HP, Henquin JC, Preissler M (1978) Potassium dependence of the membrane potential of pancreatic B-cells. FEBS Lett 94: 87-89

32. Matthews EK, Shotton PA (1984) The control of ${ }^{86} \mathrm{Rb}$ efflux from rat isolated pancreatic islets by the sulphonylureas, tolbutamide and glibenclamide. Br J Pharmacol 82: 689-700

33. Malaisse WJ, Carpinelli A, Herchuelz A (1980) Tolbutamide stimulates $\mathrm{Ca}^{2+}$ influx in islet cells without reducing $\mathrm{K}^{+}$conductance. Diabetologia 19: 85 (Letter)

34. Henquin JC, Meissner HP (1981) Effects of amino acids on membrane potential and ${ }^{86} \mathrm{Rb}^{+}$fluxes in pancreatic B-cells. Am J Physiol 240: E245-E252

35. Carpinelli AR, Malaisse WJ (1981) Regulation of ${ }^{86} \mathrm{Rb}$ outflow from pancreatic islets: the dual effect of nutrient secretagogues. $J$ Physiol 315: 143-156

36. Paolisso G, Nenquin M, Schmeer W, Mathot F, Meissner HP, Henquin JC (1985) Sparteine increases insulin release by decreasing the $\mathrm{K}^{+}$permeability of the B-cell membrane. Biochem Pharmacol 34: 2355-2361

Received: 2 April 1985

and in revised form: 24 June 1985

Dr J.C. Henquin

Unité de Diabétologie et Nutrition

UCL 54.74

Avenue Hippocrate, 54

B-1200 Brussels

Belgium 